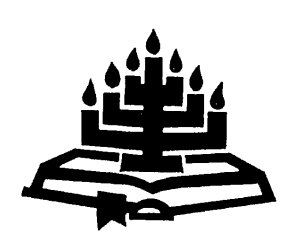

\title{
Die prediker as toeruster van die gemeente: basisteoretiese perspektiewe vanuit Hebreërs
}

\author{
F.P. Kruger \& C.J.H. Venter
}

Vakgroep Praktiese Teologie

Skool vir Kerkwetenskappe

Potchefstroomse Universiteit vir $\mathrm{CHO}$

POTCHEFSTROOM

E-pos: fercel@lantic.net

dmscjhv@puknet.puk.ac.za

\section{Abstract}

The preacher and his task of equipping the congregation:

Basis-theoretical perspectives from the Hebrews sermon

In this article an attempt is made to indicate that preachers should be conscious of their task of equipping the congregation. Expressions in which the preacher, his conduct, his relation to other people and his spirituality are stated explicitly are investigated. The authors deal with basis-theoretical material taken from Hebrews. In the Hebrews sermon the preacher is indicated as therapist, leader, minister and shepherd. The preacher is also perceived of as servant and mouthpiece in the liturgy of the congregation. This exposition is followed by perspectives for the praxis of equipment in ministering the Word to the congregation.

\section{Opsomming}

Die prediker as toeruster van die gemeente: basisteoretiese perspektiewe vanuit Hebreërs

In hierdie artikel probeer die outeurs aantoon dat predikers erns behoort te maak met hulle taak om die gemeente toe te rus. Die klem word geplaas op sekere uitdrukkings in die Hebreërspreek wat direk te make het met wie die prediker is, sy optrede, sy verhouding teenoor ander mense asook sy spiritualiteit. Die outeurs fokus op basisteoretiese gegewens wat vanuit Hebreërs ontgin word. In die Hebreërspreek word die prediker beskryf as 'n terapeut, 'n leier, 'n bedienaar van die Woord en 'n herder. Die prediker word verder ook beskryf as 'n dienskneg en mondstuk in die liturgie. Ten slotte word perspektiewe met die oog op die praktyk van die toerusting van die gemeente deur middel van die prediking gebied. 


\section{Inleiding}

In homiletiese navorsing die afgelope tien jaar is 'n sterk gerigtheid op die rol van die prediker in die toerusting van die gemeente (Askes, 1990:454; Mitchell, 1993:228; Van den Berg \& Dreyer, 1994:709 \& Pieterse, 2001:28). Vroeër is die klem in navorsing in die besonder geplaas op die vraag of die prediking nog die moderne mens raak (Vorster, 1995:443). Tans word die klem nie net op die prediking nie, maar ook op die rol van die prediker geplaas (Duduit, 1996:9; Wiersbe, 1995:13; Burger, 1995:60; Smit, 1995:12 \& Van der Merwe, 1995:140). Van der Vyver en Venter (2000:174-175) het onder andere die prediker se verantwoordelikheid om hoorders te begelei, aangetoon. Genoemde outeurs toon aan dat die persoon van die prediker, sy integriteit en geloofwaardigheid 'n groot rol speel in die kommunikasiegebeure van die prediking.

De Klerk (1998:75) asook Van Wyk (1998:10) besin op kritiese wyse in hulle navorsing oor die rol van die predikant in die krisis wat die kerk in oorgangstye ervaar. De Klerk (1998:75-77) verwys na enkele redes vir die krisis wat die kerk ervaar:

- Sommige predikante is nie toegerus om goeie predikante te wees nie, dalk vanweë gebrekkige opleiding.

- Ander predikante het 'n ontoereikende persoonlikheid wat as struikelblok dien in die dienswerk as predikant.

- De Klerk toon aan dat daar wel ook predikante is wat aan al die formele vereistes voldoen, maar hulle kan nie preek nie.

Vanuit bogenoemde navorsing blyk die aktualiteit van hierdie onderwerp wat handel oor die rol van die predikant in die toerusting van die gemeente. Die uitgangspunt van hierdie artikel is dat die prediker as instrument ' $n$ groot rol speel in die toerusting van die gemeente. Die sentrale doelstelling met die artikel is die byeenbring, ordening en rangskikking van toepaslike materiaal oor die prediker as toeruster van die gemeente met die oog op die daarstelling van basisteorieë vir verdere besinning oor hierdie tema in die Praktiese Teologie. In die artikel sal primêr gefokus word op die ontginning van relevante materiaal uit die Hebreërspreek. Onder Nuwe-Testamentici bestaan daar redelike konsensus dat dié geskrif 'n preek met 'n briefslot is (Opperman, 1995:26; Ellingworth, 1993:61; Pfitzner, 1993:3; Coetzee, 1986:1-9). Aangesien Hebreërs ook as 'n preek beskou kan word, is dit noodsaaklik om toepaslike materiaal aangaande die prediker as toeruster op basisteoretiese wyse vanuit Hebreërs te ondersoek. 


\section{Basisteoretiese verkenning uit Hebreërs}

Hebreërs as 'n preek is fyn en kunstig gestruktureer met 'n verhewe taalgebruik (Kistemaker, 1984:6). Die volgende kort strukturele uiteensetting van die struktuur van Hebreërs kan moontlik daartoe bydra om bogenoemde stelling te bevestig. Guthrie (1996:117) bied die volgende struktuur van Hebreërs:

Inleiding (Hebreërs 1:1-4): God het met ons gepraat deur sy Seun

1. Die posisie van die Seun in verhouding tot die engele (Heb.1:5-14).

2. Die posisie van die Seun, ons Hoëpriester, met betrekking tot die aardse offersisteem, met as inleiding die volgende gedagte: ons het 'n sondelose Hoëpriester wat die hemel ingegaan het (Heb. 4:14-10:18).

3. Slot: Ons het 'n groot Hoëpriester wat ons die hemel inneem (Heb. 10:19-25).

\subsection{Begrippe vir prediker vanuit Hebreërs}

Die volgende begrippe word in die Hebreërspreek vir die prediker gebruik:

- $\theta \epsilon \rho a ́ \pi \omega \nu$ (Heb. 3:5)

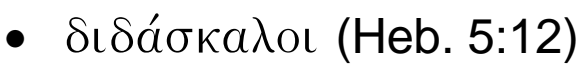

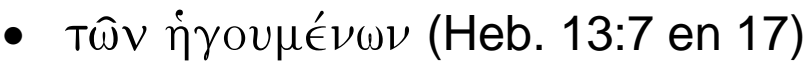

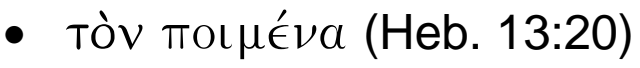

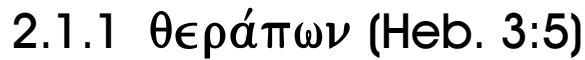

In Hebreërs 3:2 het die Hebreërsskrywer Jesus en Moses met mekaar vergelyk. In Hebreërs 3:5 gaan hy verder deur die verskil tussen hulle aan te dui. Die verskil kan soos volg aangedui word:

\begin{tabular}{|c|c|}
\hline Moses & Jesus \\
\hline 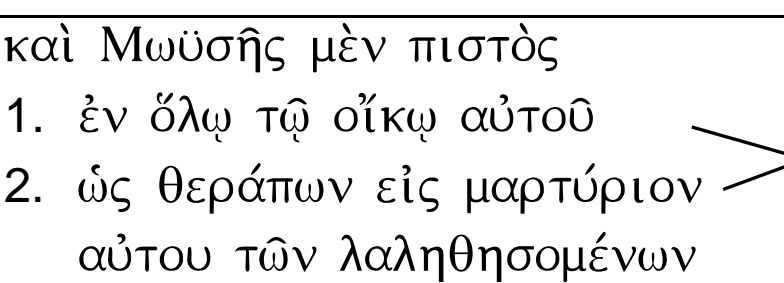 & 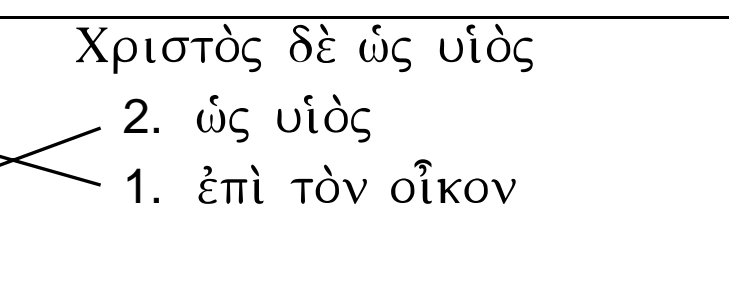 \\
\hline $\begin{array}{l}\text { En Moses was wel getrou in sy } \\
\text { hele huis as 'n dienaar om te } \\
\text { getuig van wat nog gespreek moet } \\
\text { word. }\end{array}$ & $\begin{array}{l}\text { maar Christus as Seun oor sy } \\
\text { huis. }\end{array}$ \\
\hline
\end{tabular}


Moses was 'n dienaar in God se huis, terwyl Jesus Seun oor sy huis is. Die Hebreërs-prediker gebruik die term $\theta \epsilon \rho a ́ \pi \omega \nu$ om Moses mee te beskryf. In Hebreërs 3:5-6 word 'n chiasme aangetref. Die inversie van elemente 1 en 2 in vers $6 a$ bring mee dat die chiasme met vers 5 gevorm word. Op dié wyse word die begrip $\theta \epsilon \rho a ́ \pi \omega \nu$ beklemtoon, aangesien die volgorde van woorde in die aanhaling uit Numeri 12:7 gewysig word (Ellingworth, 1993:206). Terselfdertyd word ví̀s ook beklemtoon deur die woord nader aan die begin van die sin te plaas (Kistemaker, 1984: 84). Aan die einde van vers 5 word 'n a-simmetriese frase aange-

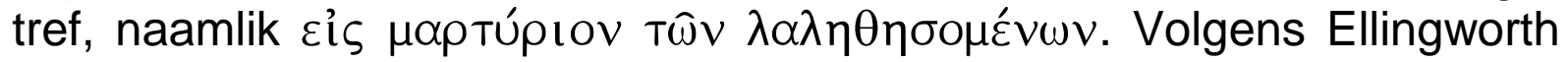
(1993:207) word dié frase so gebruik om die verskil sowel as die ooreenstemming tussen Moses en Jesus te benadruk.

In die Nuwe Testament word die volgende begrippe gebruik om diens

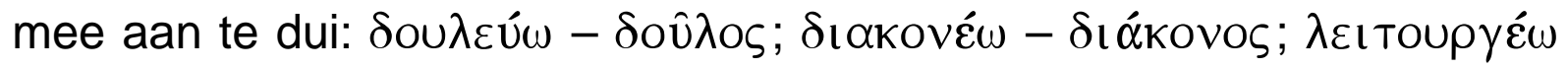

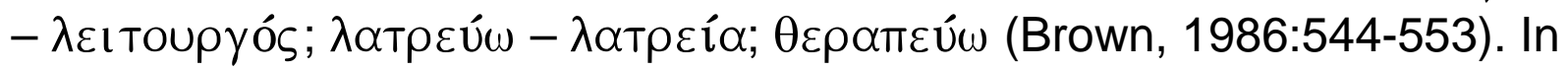
Hebreërs 3:5 word die minder bekende term $\theta \epsilon \rho \alpha \dot{\alpha} \pi \omega \nu$ gebruik om Moses as dienaar mee te beskryf. Die begrip word in dié vorm net een maal in die Nuwe Testament en wel in Hebreërs 3:5 gebruik. Louw en Nida (1989:460) plaas dié begrip binne die subdomein van diens. Die begrip het die betekenis van om bystand aan te bied, om sekere pligte uit te voer, om te help (Louw en Nida, 1989:460). 'n Dienende oftewel nederige gesindheid is onderliggend aan dié begrip (Louw en Nida, 1989: 460). Die begrip benadruk die bereidwilligheid van die dienaar om so goed as moontlik te dien (Smith, 1984:79). Die begrip $\theta \epsilon \rho a \pi \epsilon \dot{\omega} \omega$ het volgens Brown (1986:163-164) selfs die betekenis van genesing. Flanigan (1997:65) toon in sy navorsing aan dat die begrip betrekking het op die diens in die huis van God - diens wat gemik is op die gesonde stand van sake in die huishouding. Volgens Louw (1993:26) moet die dimensie van genees en herstel in die begrip $\theta \epsilon \rho a ́ t \omega \nu$ bemerk word. Genees en herstel het 'n tekenkarakter wat gelowiges se aandag vestig op dit wat Jesus Christus gedoen het (Bromiley, 1985a:332). Prediking het dus 'n terapeutiese funksie in dié opsig dat dit die herstel van die band van die gelowige met God in alle opsigte in die oog het.

\section{Basisteoretiese afleiding}

Bogenoemde begrip word slegs een maal in die Nuwe Testament, naamlik in Hebreërs 3:5 gebruik. Die volgende afleiding kan op grond van die voorafgaande toeligting gemaak word:

'n Prediker is 'n persoon wat ander dien in die gesindheid van bereidwilligheid (diensvaardigheid) en deur sy Woordbediening genesing bring. 


\subsection{2 $\Delta \mathrm{t} \delta \alpha ́ \sigma \kappa \alpha \lambda \circ \varsigma$ (Heb. 5:12)}

In Hebreërs 5:11-14 onderbreek die skrywer homself. Hy is besig om 'n uiteensetting te gee van Christus se priesterskap, maar vanweë die gesindheidsprobleem wat die hoorders ervaar, onderbreek hy homself om as leermeester sy hoorders op te skerp (Vines, 1993:81). Vanweë die prediking wat tot hulle gekom het, moes hulle self al leermeesters gewees het. Hulle moes onderwysers gewees het, maar is eintlik nog leerlinge (Evans, 1984:128). Die begrip $\delta ı \delta \alpha ́ \sigma \kappa a \lambda o s$ word hier binne die raamwerk van die traagheid van die hoorders gebruik.

Louw en Nida (1989:413) plaas dié begrip binne die subdomein van onderrig gee. Onderrig gee is 'n subdomein van die begrip kommunikasie (Louw \& Nida, 1989:388). 'n $\Delta \mathrm{t} \delta \alpha \sigma \sigma \kappa a \lambda o s$ is iemand wat die onderrig oftewel instruksie verskaf (Louw \& Nida, 1989:416). Kim en Venter (1999:519) asook Louw (1993:29) dui aan dat die begrip gebruik word binne die raamwerk van die opbou van gelowiges. Geloofsopbou wat lei tot geloofsvolwassenheid is 'n sentrale moment in die begrip. Die prediker as $\delta \iota \delta \alpha ́ \sigma \kappa a \lambda o s$ word geroep om deur middel van onderrig oortuigings te vorm en te verander wat nie in ooreenstemming met God se Woord is nie (Brown, 1994:268; Pfitzner, 1993:6). Bromiley (1985b: 163) voeg selfs by dat die term $\delta \iota \delta \alpha ́ \sigma \kappa a \lambda o s$ veral van toepassing is op die sistematiese onderrig wat geskied.

\section{Basisteoretiese afleidings}

- Die prediker as leraar word geroep om die gemeente te onderrig in die waarhede van die Woord.

- Die begrip $\delta ı \delta \alpha ́ \sigma \kappa a \lambda o s$ word gebruik binne die raamwerk van die opbou van gelowiges tot geloofsgroei. 'n Prediker moet die gemeente deur Woordbediening opbou tot geloofsgroei.

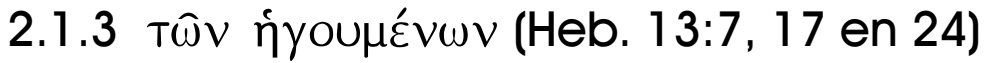

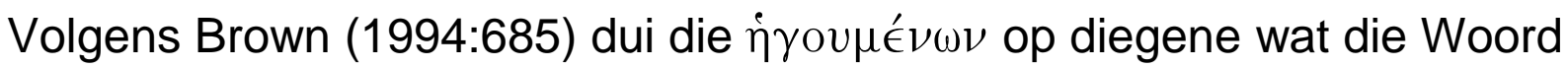
verkondig het. In Hebreërs 13 word drie maal melding gemaak van die leiers. Barton et al. (1997:234) en Guthrie (1996:270) toon aan dat die begrip in die Hebreërspreek 'n tegniese oftewel amptelike aard het. Louw en Nida (1989:465) plaas die begrip binne die subdomein van leiding, dissipline en navolging. Die begrip $\dot{\gamma} \gamma о u \mu \epsilon ́ \nu \omega \nu$ dui op die invloed wat die prediker op ander uitoefen sodat hulle die aanbevole weg van aksie navolg (Louw \& Nida, 1989:465). Die begrip dui dus die begeleidingtaak van die prediker aan.

Van der Merwe (1995:101) sluit by bogenoemde gedagtes aan en benadruk die rol van die prediker as leier. In dié opsig is die prediker se 
voorbeeld deurslaggewend. Predikers moet die waardes wat die Woord voorhou op spontane en natuurlike wyse deur hul voorbeeld uitleef en sodoende demonstreer. 'n Prediker (begeleier) wie se optrede geloofwaardig is, inspireer en motiveer gelowiges. Die teendeel is egter ook waar (Van der Merwe, 1995:101). Smit (1995:12) dui in sy navorsing aan dat die leierskap van die prediker nie in die eerste plek dui op sy funksie nie, maar op wie hy voor God en tussen ander mense is. Deur die voorbeeld wat die prediker stel, moet hy aantoon dat dit wat hy preek (verkondig), ook in sy persoonlike lewe vergestalt word. Die wees- en doenfunksie van die prediker moet dus kongruent wees.

Richards en Hoeldtke (1980:138) asook Pfitzner (1993:6) toon aan dat die doel van die prediker as leier is om gelowiges te help soek na antwoorde, te bring by insig en om hulle te begelei om God se wil na te volg. Die begrip $\pi \in \epsilon^{\prime} \theta \in \sigma \theta \epsilon$ (gehoorsaam) in Hebreërs 13:17 beteken dat gelowiges hulle moet laat oortuig of oorreed deur hulle leiers wat die Woord reg en suiwer verkondig (Richards \& Hoeldtke, 1980:140). Die hoorders word sodoende opgeroep tot 'n gesindheid van gewilligheid en samewerking om deur hulle leiers oorreed of begelei te word tot verandering (Bruce, 1990:385). In Hebreërs 13:17 word bygevoeg dat

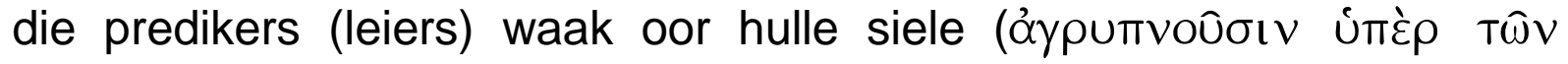

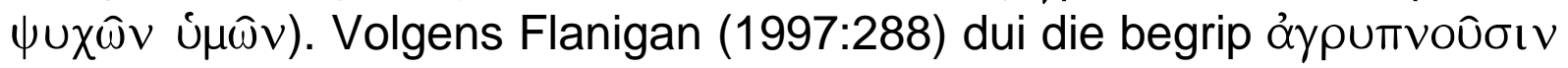
op die waaksaamheid en selfs slapeloosheid van die leiers oor die kudde. Bruce (1990:386) wys daarop dat die gewigtige opdrag van die leiers aanleiding gee tot hulle slapeloosheid oor die kudde. In Hebreërs 13:17 word gehandel oor die predikers wat nog onder die gelowiges optree. Die predikers moet die geestelike verantwoordelikheid daarvoor neem om op geestelike gebied te waak oor gelowiges (Barton et al., 1997:242). Indien die prediker sy roeping ernstig opneem, hou hy op geestelike gebied wag oor gelowiges (Kistemaker, 1984:426). Hiermee word die erns van die begeleidingtaak van die prediker uitgedruk.

\section{Basisteoretiese afleiding}

Die volgende afleiding kan gemaak word:

'n Prediker is 'n begeleier tot verandering, onder andere op grond van sy optrede en die erns waarmee hy sy roeping bejeën.

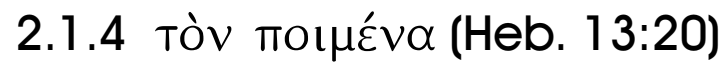

In die voorafgaande verse het die Hebreërsskrywer die gelowiges opgeroep om te dink aan hulle voorgangers. In Hebreërs 13:18-21 gaan hy daartoe oor om vir die gelowiges te bid (Vines, 1993:251). In die gebed hou die Hebreërsskrywer die feit in gedagte dat Jesus die Groot Hoëpriester is. Hebreërs 13:20 is die enigste plek in die preek waar 
Christus die Opperherder genoem word. Elders in die Bybel word die

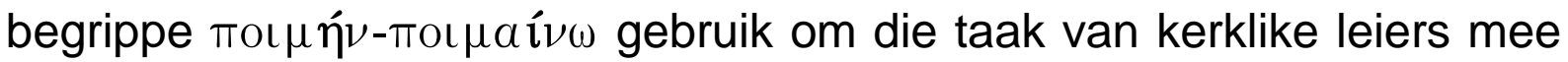
aan te dui (Ellingworth, 1991:729). Hier word Christus nie bloot met

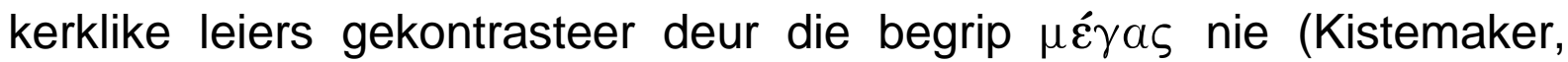
1984:430). In Hebreërs 4:14 en Hebreërs 10:21 is daar ook melding van Christus as die groot Hoëpriester. Tog druk die byvoeglike naamwoord "groot" nie net die kontras tussen Christus as Opperherder en menslike herders uit nie, maar dui dit ook op 'n gesindheid van afhanklikheid teenoor die Opperherder (Mack \& Swavely, 1996:166). Die dubbele gedagte van lei en omgee is dus onderliggend aan die begrip (Bromiley, 1985c:903).

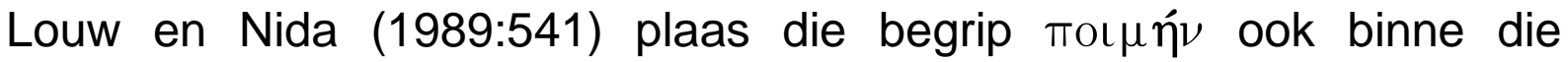
subdomein van die rol en funksie wat geestelike leiers kry om te verrig. Dié begrip het die betekenis van om verantwoordelik te wees vir die sorg en leiding van die gemeente. Die begrip kan ook pastor beteken. Oostenbrink en Lotter (1999:47) wys op die pneumatologiese vertrekpunt in die herder-metafoor. Die prediker is nie toevallig as herder daar nie, maar is deur die Heilige Gees begenadig met gawes en deur die Heilige Gees geroep (innerlik en uiterlik). Daarom is dit noodsaaklik dat die prediker as herder homself ook moet oppas. Die oppas behels dat predikers ten opsigte van die getrouheid in hulle eie geloofslewens 'n voorbeeld moet stel. Louw (1993:25) sien die unieke van die metafoor daarin dat die deernisvolle bediening in 'n noue verband staan met Jesus Christus se opofferende liefde vir sy kudde. In die herderlike dimensie van prediking moet God se sorgsame bystand aan sy kudde bemerk word.

\section{Basisteoretiese afleidings}

- Die prediker as herder moet God se sorgsame bystand vir die gemeente merkbaar laat word deur sy sorg vir die gemeente.

- Die prediker as herder moet homself oppas. Deur homself ten opsigte van getrouheid in sy geloofslewe op te pas, dien die prediker as sigbare voorbeeld van God se sorg vir die gemeente.

\subsubsection{Samevatting}

In die Hebreërspreek word die volgende begrippe vir prediker gebruik:

- Die prediker as terapeut. Die prediker moet in die dienswerk fokus op die herstel van die band tussen God en gelowige.

- Die prediker as leier. Dié begrip dui die begeleidingstaak van die prediker aan. Hy moet die gemeente begelei met wat hy doen en sê. 
- Die prediker as leraar. Die prediker word as leraar geroep om die gemeente te onderrig in die Woord van die Here.

- Die prediker as herder. Die prediker as diensknegherder staan in diens van die Opperherder Jesus Christus. Deurdat die prediker oor homself waak, kan hy ook oor ander waak.

\subsection{Die optrede van die prediker}

In die Praktiese Teologie benadruk homilete die verhouding waarin die prediker teenoor die hoorders staan (Pieterse, 2001:28; Willhite, 1992: 355). Daarom is dit noodsaaklik om benewens die begrippe wat vir die prediker in Hebreërs gebruik word, ook te let op gegewens wat lig werp op die optrede van die prediker. Die optrede van die prediker word veral vanuit drie kante in die Hebreërspreek belig:

- Die prediker as dienskneg in die gebou van God.

- Die prediker as mondstuk in die liturgie van die gemeente.

- Die prediker as iemand wat verhouding bou.

\subsubsection{Die prediker as dienskneg in die gebou van God}

In punt 2.1.1 is die begrip dienaar $(\theta \epsilon \rho \tilde{\alpha} \pi \omega \nu)$ alreeds bespreek. In dié paragraaf sal die begrip bespreek word met die toespitsing op die optrede van die prediker in die huis van God. In Hebreërs 3:1-6 word 'n vergelyking aangetref tussen die Seun en die beroemde geloofsvader, Moses (Barton et al., 1997:31). In die voorafgaande gedeelte het die skrywer die grootheid van die Seun aangetoon. In dié gedeelte toon die skrywer aan dat die Seun groter is as die beroemde Moses. Die sentrale gedagte in Hebreërs 3:1-6 word gevind in die term huis (oî́os) (Brown, 1994:159). Die term oîkos dui nie op die struktuur van 'n gebou nie (Ellingworth, 1993:197; Mahan, 1989:14). Bruce (1990:92) sluit in sy verklaring hierby aan deur die begrip as 'n sinoniem vir die gesin van God te sien. Die term dui dus op die Christelike huishouding of Christelike kerk (Briscoe, 1994:80 \& Kittel \& Friedrich, 1985:675).

Moses is deur God aangestel oor die huisgesin van God (Brown, 1994: 159). God is die Argitek wat Christus aangestel het as Boumeester van sy huis (Evans, 1984:83). Die kerk is die skepping van God. In die huis wat deur God gebou word, is Moses 'n dienaar. Voordat Moses nog in die huis gedien het, het die huis van God al bestaan (Kistemaker, 1984:85). In Hebreërs 3:1-6 word die saak soos volg gestel:

- God is die Argitek van die gebou. 
- Jesus Christus is die Bouer.

- Moses is die dienaar in die gebou.

Met die duidelike onderskeid wat tussen Christus en Moses getref word, word die belang van die werk van Moses nie ontken nie (Hume, 1997:34; Bromiley, 1985d:674-676; Vines, 1993:45). Tog stel die gedeelte dit duidelik dat geen vergelyking tussen Christus en Moses moontlik is nie. Christus is die Bouer en Stigter van die huis waarvan Moses self ' $n$ lid is en waarbinne hy as dienaar optree.

Venter (1986:7) toon aan dat teenoor die verval van die gelowiges die opbou van gelowiges in Hebreërs gestel word. Die boukonsep (Heb. 3:16) asook die groeikonsep (Heb. 5:12-14) kom in die preek na vore.

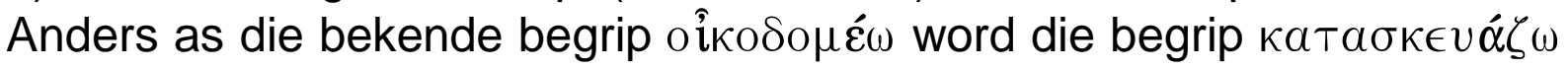
in Hebreërs 3:1-6 gebruik (Flanigan, 1997:65). Binne die wyer konteks van Hebreërs waarin skadu en werklikheid 'n prominente rol speel, soos onder andere in Hebreërs 3:1-6 met die vergelyking tussen Christus en Moses, het die begrip 'n eie betekenisnuanse. Louw en Nida (1989:683) plaas die begrip binne die subdomein van gereed of voorbereid. Die betekenisnuanse van om daartoe by te dra om iets of iemand voor te berei of om die weg voor te berei is onderliggend aan die begrip (Louw en Nida, 1989:684). Die toerusting met die oog op gereedheid dien as

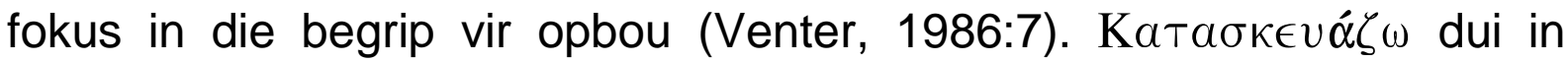
Hebreërs op die opbou en toerusting van die gelowiges.

Die prediker wat as dienaar getrou is in die huis van God, moet daarom deur middel van sy prediking voorberei en toerus. In die kerk van Christus word die prediker as dienaar geroep om die Woord te bedien. Kim en Venter (1999:518) toon aan dat die verkondiging van die Woord as instrument van die Heilige Gees 'n belangrike wyse is waarop die gemeente toegerus word, omdat dit lei tot geloofsvolwassenheid. Daarom is dit noodsaaklik dat die prediker preke sal lewer wat relevant is in die konteks van hier en nou (Willhite, 1992:357). Sodoende dra die prediker by tot die toerusting van gelowiges met die oog op die uitdagings van elke dag (Vasquez, 2000:11).

\section{Basisteoretiese afleidings}

- Die prediker word deur God geroep as dienskneg om in God se huis (die kerk) die Woord te bedien.

- Die prediker moet rekening hou met die trinitariese oorsprong van die kerk.

- Die prediker moet deur middel van prediking voorberei en toerus met die oog op die daaglikse lewe. 


\subsubsection{Die prediker as liturg}

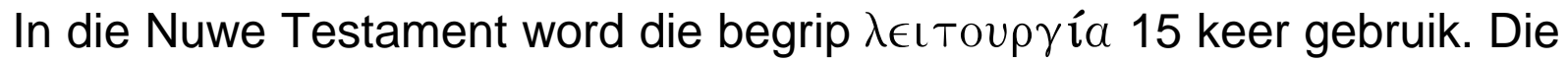
begrip kom ses maal in Hebreërs voor, naamlik in Hebreërs 1:7, Hebreërs 1:14, Hebreërs 8:1, Hebreërs 8:6, Hebreërs 9:21 en Hebreërs 10:11. Liturgie is iets wat verrig word deur 'n persoon wat God op 'n besondere wyse dien (Barton et al., 1997:155). Die ware en enigste Liturg is Jesus Christus (Guthrie, 1996:207). In die Septuaginta word dié woord gebruik vir amptelike dienswerk in die erediens (Van der Walt, 1984:3). In die Nuwe Testament word 'n uitbreiding van die begrip aangetref, naamlik as die diens van gelowiges aan God (Kittel \& Friedrich, 1985:527).

In Hebreërs 8:2 word Christus die bedienaar ( $\lambda \varepsilon$ ıтоupyós) van die heiligdom genoem. In Hebreërs $8: 6$ is sprake van 'n voortrefliker

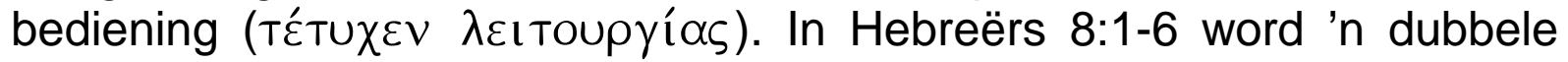
kontras tussen Jesus Christus en die Levitiese priesters aangetref (Ellingworth, 1993:398). In albei gevalle word positiewe en negatiewe sake gemeld. Ellingworth (1993:399) beskou die perikoop as 'n sillogisme. ' $n$ Sillogisme is ' $n$ redenasie wat uit twee premisse bestaan waaruit 'n konklusie afgelei word. 'n Sillogisme sou ook 'n sluitrede genoem kan word. Die sillogisme sien soos volg uit:

- Hoofstelling - Jesus is 'n hoëpriester (vers 1)

- Sekondêre stelling - Jesus kan nie 'n aardse priester wees nie (vers 4)

- Konklusie - Jesus moet 'n priester in die hemel wees (vers 6).

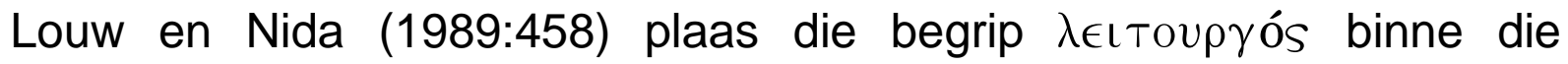
subdomein van help, omgee of dien. Die begrip is ' $n$ aanduiding van iemand wat 'n spesiale diens verrig (Louw \& Nida, 1989:461). Die begrip $\lambda \in \iota$ Toup rı a dui op die bediening wat deur 'n persoon verrig word (Louw \& Nida, 1989:461). Nel (1994:37) toon aan dat bediening 'n handeling is wat in die Naam van Jesus Christus onderneem word. Dit is immers Jesus Christus se $\lambda \epsilon \iota$ Tovpría (voortreflike priesterdiens) wat die weg na God open. Die priesters van die ou bedeling kon nooit gaan sit het nie. Hulle moes voortdurend besig wees met hulle dienswerk (Guthrie, 1996:207). Jesus Christus het sy dienswerk vir eens en altyd gelewer en toe vir altyd gaan sit aan die regterhand van God. Jesus Christus se bediening gee ook betekenis aan die begrip liturgie. Deur die diens wat onder die erediens gelewer word, moet gelowiges gevoed word. Die prediker is die persoon wat geroep en toegerus is om God se Woord aan die gemeente te bedien (Barnard, 1994:437). Brown (1986:551) toon aan 
dat die begrip $\lambda \epsilon \iota \mathrm{Tou} \rho \gamma \varepsilon \dot{\varepsilon} \omega$ (diens van die volk) die teenoorgestelde is van werk vir jou eie belang.

Die Hebreërspreek toon aan dat die Ou-Testamentiese priesterlike offerdiens in Christus sy doelwit bereik het (Van der Walt, 1984:4). Op grond hiervan kom Van der Walt tot die gevolgtrekking dat die gestuurdes van Christus nie nodig het om 'n liturgie vir die gelowiges te vervul nie. Hulle taak is om die woord van die kruis te verkondig as die liturgie wat vervul is. Die gemeente het geen priesters nie, want die gemeente self is priesters (Brown, 1994:361). Die benaming van die predikant as liturg is 'n teruggryp na die Ou Testament (Brown, 1986: 552). Van der Walt (1984:8) bied 'n oplossing vir die problematiek deur aan te toon dat die plek van die liturg is om vriend van die Bruidegom te wees (Joh. 3:29). Die liturg (predikant) is nooit self aan die woord nie. Onder die erediens is die predikant bloot mondstuk van God of die gemeente in die tweerigtinggesprek van die liturgie. Die gemeente moet dus self die erediens aan God verrig. Müller (1990:23) dui die erns van eredienste aan deur daarop te wys dat die predikant se taak by die erediens begin en daarheen teruglei. Die liturgie van die erediens eindig immers nie aan die einde van die erediens nie, maar loop uit op die liturgie van die lewe. 'n Erediens is 'n trefpunt tussen God en die mens (Dingemans, 1991:43). Die prediking as deel van die liturgie onder die erediens moet daartoe bydra dat die gemeente in gesprek tree met God. Hierin is die prediker 'n dienaar.

\section{Basisteoretiese afleidings}

- Die prediker is onder die erediens 'n mondstuk van God en die gemeente.

- Die prediker kom nooit self aan die woord nie. Prediking moet daartoe bydra dat die gemeente self haar liturgie (diens aan God) verrig.

- Die prediker se taak is om die Woord te verkondig van die liturgie wat reeds in Christus vervul is.

- Die prediker se optrede onder die erediens moet getuig van 'n dienskneggestalte. Die prediker mag nooit in die weg staan van die ontmoeting tussen God en sy gemeente nie.

\subsubsection{Die prediker as man van verhouding}

Kim en Venter (1999:173) meen dat die predikant betrokke is by veelvoudige verhoudings soos onder andere met God, met sy gesin, met die gemeente en met die gemeenskap. Bogenoemde outeurs stel dit dat die kwaliteit van die predikant se dienswerk grootliks afhang van die per- 
soonlike en pastorale verhouding teenoor diegene wat hy met die Woord bedien (Kim \& Venter, 1999:173).

Die Hebreërsprediker se verhouding met die gemeente word gekenmerk deur 'n gemeenskapsgedagte (Venter, 1986:17). Die gedagte kom veral in twee perikope duidelik na vore, naamlik Hebreërs 3:1-19 en Hebreërs 10:19-25. Albei gedeeltes is vermanend bemoedigende toepassings in die Hebreërspreek. In Hebreërs 3:1 spreek die prediker die hoorders vir die eerste keer aan as "heilige broeders, deelgenote van die hemelse

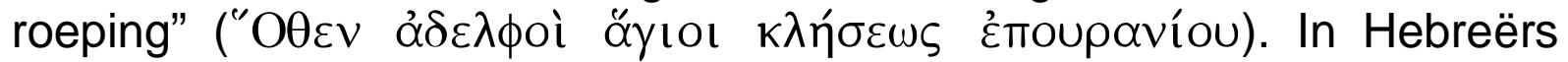

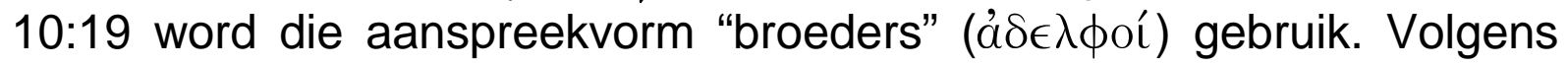
Venter (1986:17) dui die gebruik van die aanspreekvorm wat telkens in die toepassing van die preek gebruik word, op die gemeenskapgedagte wat in die preek vooropstaan. Volgens Barton et al. (1997:159) wil die Hebreërsprediker die gelowiges vooraf oortuig van sy broederlike gesindheid teenoor hulle. In Hebreërs 2:11 het die prediker klaar aangetoon dat God se kind in Christus geheilig is. As gelowiges is hulle daarom vir God afgesonder.

Al spreek die prediker in Hebreërs sy hoorders skerp aan, bly hulle heilige broeders (Kistemaker, 1984:83). Volgens Guthrie (1996:211) is die benaming ' $n$ aanduiding daarvan dat die prediker hom een voel met die gemeente, vanweë die feit dat toegang tot God ook 'n nuwe onderlinge verhouding veronderstel. ' $n$ Broederlike gesindheid word hiermee aangedui. Die geloofsgemeenskap van die gelowiges lê opgesluit in:

- die feit dat een en dieselfde Hoëpriester, Jesus Christus, sy huis toerus en regeer;

- die gemeenskaplike belydenis in hoofstuk 3 en 10; die gemeenskaplike belydenis van Christus se hoëpriesterskap bind die huisgenote van God se huis saam.

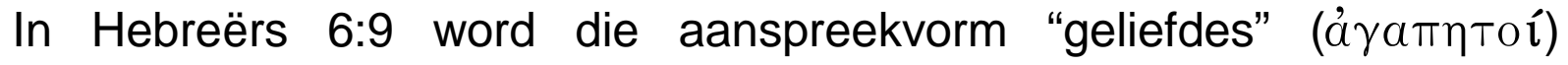
gebruik. Nadat die prediker sy hoorders in die voorafgaande verse skerp vermaan het, gaan hy daartoe oor om teer woorde wat getuig van liefde tot hulle te spreek (Hume, 1997:52). Volgens Hume kom die prediker se pastorale besorgdheid in die uitdrukking geliefdes na vore. In sy besorgdheid wil die prediker nie sy hoorders tot moedeloosheid dryf nie. Daarom verseker hy die gelowiges daarvan dat hy van beter dinge aangaande hulle oortuig is. Burger (1995:90) is op grond hiervan van mening dat aan die hoop van 'n geloofsgemeenskap nie primêr gebou word deur prediking wat net vermanend van aard is nie, maar ook deur prediking wat herinner aan 'n ander dieper werklikheid (vgl. ook Heb. 6:9). 
In Hebreërs 11 het die prediker nie net die hoorders nie, maar ook homself gebind aan die les van die geloofshelde uit die geskiedenis. Hiermee wou hy die saak van geloofsvolharding opnuut onderstreep (Russell, 1996:141). In Hebreërs 12 word aanwys en afwys, vermaning en toeligting op afwisselende wyse gebruik. Vanuit die toeligting dat Jesus die Begin en Voleinder van die geloof is, spruit die opdrag voort dat gelowiges ag moet slaan hierop. In die geloofswedloop moet gelowiges op die regte wyse gefokus bly. Die volgende aspekte van die verhouding van die prediker tot die gelowiges kom in Hebreërs na vore:

- Daar het 'n goeie verhouding tussen die prediker en die gemeente bestaan. Daarom kan die prediker ook die gelowiges skerp vermaan.

- In sy prediking het die prediker 'n unieke toespitsing wat bepaal word deur die situasie van sy hoorders. Binne hierdie situasie word sy prediking ingerig volgens die eie en unieke aard van die omstandighede van die gemeente.

\subsection{Die spiritualiteit van die prediker}

Die prediker beïnvloed mense met sy prediking. Firet (1978:298) gebruik die term agogie vir die beïnvloedingsgebeure. Hiermee vestig hy opnuut weer die aandag op die predikant as agoog (Louw, 1987:66). Louw (1987:66) is van mening dat die prediker 'n diepe geestelikheid of spiritualiteit benodig om op die regte wyse die gemeente te kan begelei.

Die term spiritualiteit gee uitdrukking aan die wyse waarop die prediker aan God verbonde is en dui derhalwe op die geestelike oriëntasie van die prediker. Venter (1999:200) maak in sy navorsing oor die spiritualiteit van die bedienaar met verwysing na sy toerustingstaak die volgende afleidings:

- Die spiritualiteit van die bedienaar moet pneumatologies gefundeer en beoefen word.

- Daar bestaan 'n wisselwerking tussen die spiritualiteit van die bedienaar en die gemeente.

- Die beoefening van die spiritualiteit deur die bedienaar en die gemeente vind plaas deur voeding daarvan uit die Woord.

- Groei in die bedienaar se spiritualiteit moet deur die gemeente gesien word.

- Gebrek aan groei in die spiritualiteit van die bedienaar werk remmend in op die toerusting van die gemeente tot geestelike groei. 
Mahan (1989:73) is van mening dat die gelowiges in Hebreërs 13:7 opgeroep word om stip te let op die goeie voorbeeld wat die predikers aan hulle gestel het. Die voorbeeld wat hulle met hul lewenswandel gestel het, was navolgenswaardig. Volgens Ellingworth (1993:701) dui die opdrag rondom die leiers op 'n strukturele merker binne die konteks waar gehandel word oor die innerlike geestelike lewe van die gelowiges. Die gelowiges word opgeroep om hulle voorgangers wat aan hulle bekend is, en in die bediening van die Woord voorgaan, te gedenk (Evans, 1984:246). Die begrip $\mu \nu \eta \mu \nu \nu \in \dot{\epsilon} \in T \epsilon$ het die betekenis van in gedagte hou. Volgens Flanigan (1997:282) word die volgende beskrywing van die leiers in Hebreërs 13 aangetref:

- Hulle het die Woord verkondig.

- Sommige van die predikers is reeds oorlede.

- Die predikers se lewe het getuig van lojaliteit aan God. Die geloofsvoorbeeld wat die predikers gestel het, moet deur die hoorders nagevolg word. Die opdrag wat die gelowiges ontvang, is om die uiteinde van die voorgangers se lewenswandel te aanskou en hul geloof na te

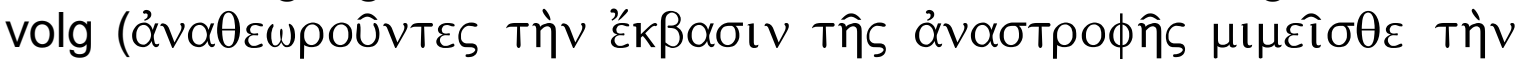

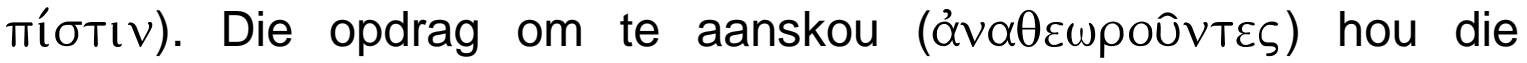
gedagte in van teoretiseer of analiseer (Evans, 1984:246). Die begrip beteken dat gelowiges opnuut, vir 'n tweede maal of versigtig, moet let op die voorbeeld van hulle voorgangers. Die begrip vir voorbeeld, naamlik Tท̂s ở $\alpha \sigma т \rho о \phi \hat{n} s$ beteken om in 'n ander rigting te gaan. Vanuit die leiers se voorbeeld moet dit duidelik blyk dat hulle 'n nuwe veranderde lewenstyl het wat ooreenstem met dit wat hulle verkondig (Brown, 1994:690).

Kim (1997:164) kom in sy navorsing tot die bevinding dat die spiritualiteit van die prediker nie vanselfsprekend kom nie. Daarom is dit nodig dat die prediker homself sal voed met die woorde van die goeie leer en lewe (Venter, 1988:151). Deurdat die prediker homself voed, kan hy ook die gemeente deur middel van die prediking voed. Kim (1997:165) toon drie noodsaaklike elemente in die beoefening van die prediker se spiritualiteit aan:

- 'n Voortdurende inname van die Woord.

- Die gebeure rondom prediking moet biddend geskied.

- Die prediker moet op die Heilige Gees as eintlike Prediker bly vertrou. 


\section{Samevattende basisteoretiese bevindings ten opsigte van die prediker}

- Die begrippe vir die prediker in Hebreërs benadruk die rol van die prediker as

terapeut - in die dienswerk van die prediker moet hy gefokus bly op die herstel van die verhouding tussen God en die gelowige;

$>$ leier - die prediker het 'n verantwoordelikheid om lidmate deur die prediking te begelei;

$>$ leraar - die prediker moet die gemeente deur middel van die prediking onderrig in die Woord van God;

$>$ herder - as diensknegherder staan die prediker in diens van God. Die prediker kan slegs oor die gemeente waak indien hy ook oor homself waak.

- Die verskillende begrippe wat vir die prediker gebruik word, naamlik terapeut, leier, leraar en herder benadruk die wees-funksie van die prediker. Dit is noodsaaklik dat predikers voortdurend besin oor wie hulle werklik is. As predikers dít begryp, sal dalk voorkom word dat predikers die preekstoel so vol staan dat God se stem nie meer gehoor word nie. Die prediker mag nie méér wil wees as wat hy werklik is nie. Hoorders mag ook nie meer van predikers verwag as wat hulle is nie.

- Begrip vir die wees-funksie van die prediker stel predikers en hoorders in staat om te werk aan die regte gesindheid ten opsigte van die prediking. Die begrippe vir die prediker benadruk veral die volgende aspekte van die gesindheid van die prediker:

$>$ Die gesindheid van navolging van God en daarom ook van sy Woord in die lewe van die prediker.

Die gesindheid om ander as volgeling van God te lei.

Die gesindheid van bereidwilligheid om ander te onderrig.

$>$ Die gesindheid van 'n verantwoordelikheidsbesef om die kudde van God op te pas.

- Die gesindheid van die prediker en dié van die hoorders staan in wisselwerking met mekaar en oefen daarom ook 'n invloed op mekaar uit. Prediker en hoorders moet hulself oefen in die uitlewing van die regte gesindhede. Die oefening in die regte gesindheid vind plaas deur voortdurend te luister na wat die Woord sê.

- Die gesindheid van die prediker hou implikasies in vir sy preekvoorbereiding, eksegese, hermeneuse, die lewer van preke, preek- 
besprekings asook kritiek op preke. In al die sake moet die prediker in die regte gesindheid bedienaar van die Woord bly (vgl. ook Bromiley, 1985e:526-529).

- Die prediker moet met sy prediking toerus en opbou met die oog op die daaglikse lewe. Predikers moet te midde van oorgangtye wat tans beleef word, nog sterker gefokus wees op hulle toerustingstaak.

- Die prediker kom met sy prediking nooit self aan die woord nie. Prediking moet daartoe bydra dat lidmate self hulle diens (liturgie) aan God verrig. Die prediker het die opdrag om die Woord te verkondig van die liturgie wat reeds in Christus vervul is.

- Die prediker is betrokke by veelvoudige verhoudings soos onder andere met God, met sy gesin, met die gemeente en met die gemeenskap. Die kwaliteit van die prediker se dienswerk hang grootliks af van die persoonlike en pastorale verhouding teenoor diegene wat hy met die Woord bedien.

- Die lewe van die prediker is 'n lewe coram Deo, met ander woorde 'n lewe voor die aangesig van God. Die prediker moet homself aanhoudend voed deur 'n voortdurende inname van die Woord. Indien die prediker homself voed, kan hy ook ander met die bediening van die Woord voed.

\section{Bibliografie}

ASKES, H. 1990. Enkele opmerkings oor die hedendaagse prediker en prediker in die susterkerke soos gesien deur die bril van 'n gewone lidmaat. Nederduitse Gereformeerde Teologiese Tydskrif, 31(3):452-463.

BARNARD, A.C. 1994. In die kragveld van die Woord en Gees. Pretoria : Fourie \& Malitz.

BARTON, B.B., VEERMAN, D. \& TAYLOR, L.K. 1997. Hebrews. Wheaton : Tyndale House. (Life Application Bible Commentary.)

BRISCOE, S. 1994. Fresh air in the pulpit. Grand Rapids. Mich. : InterVarsity Press.

BROMILEY, G.W. 1985a. Therapon. (In Kittel, G. \& Friedrich, G., eds. Theological Dictionary of the New Testament. Grand Rapids, Mich. : Eerdmans. p. 331332.)

BROMILEY, G.W. 1985b. Didaskalos. (In Kittel, G. \& Friedrich, G., eds. Theological Dictionary of the New Testament. Grand Rapids, Mich. : Eerdmans. p. 161165.)

BROMILEY, G.W. 1985c. Poimena. (In Kittel, G. \& Friedrich, G., eds. Theological Dictionary of the New Testament. Grand Rapids, Mich. : Eerdmans. p. 901904.)

BROMILEY, G.W. 1985d. Oikos. (In Kittel, G. \& Friedrich, G., eds. Theological Dictionary of the New Testament. Grand Rapids, Mich. : Eerdmans. p. 674676.)

BROMILEY, G.W. 1985e. Leitourgia. (In Kittel, G. \& Friedrich, G., eds. Theological Dictionary of the New Testament. Grand Rapids, Mich. : Eerdmans. p. 526529.) 
BROWN, C. 1986. Therapon. (In Coenen, L., Beyreuther, E. \& Bietenhard, H. The New International Dictionary of the New Testament Theology II. Grand Rapids, Mich : Zondervan. p. 164-170.)

BROWN, J. 1994. Hebrews. Edinburg : Bath Press. (Geneva Series of Commentaries).

BRUCE, F.F. 1990. The Epistle to the Hebrews. Grand Rapids : Eerdmans. (The New International Commentary of the New Testament.)

BURGER, C.W. 1995. Gemeentes in transito. Vernuwingsgeleenthede in 'n oorgangstyd. Kaapstad: Lux Verbi.

COETZEE, J.C. 1986. Gedagtestruktuur van Hebreërs. Potchefstroom : Fakulteit Teologie.

DE KLERK, W. 1998. Die vreemde God en sy mense. Kaapstad : Human \& Rousseau.

DINGEMANS, G.D.J. 1991. Als hoorder onder de hoorders. Kampen : Kok.

DUDUIT, M. 1996. Communicate with power. Insights from America's top communicators. Grand Rapids : Baker Books.

ELLINGWORTH, P. 1993. Commentary on Hebrews. Grand Rapids: Eerdmans. (New International Greek Testament Commentary.)

EVANS, L.H. 1984. Hebrews. Washington : Macmillan. (The communicators commentary.)

FIRET, J. 1978. Het agogisch moment in het pastoraal optreden. Kampen : Kok.

FLANIGAN, J.M. 1997. Hebrews - What the Bible teaches. Kilmarnock : John Ritchie. (Ritchie New Testament Commentaries.)

GUTHRIE, D. 1996. Hebrews. Grand Rapids : Eerdmans. (Tyndale New Testament Commentaries.)

HUME, C.R. 1997. Reading through Hebrews. Lymington : The Spartan.

KIM, H.K.1997. Preacher and spirituality: A diaconiological study in the light of the Pastoral Epistles. Potchefstroom : PU vir CHO. (Verhandeling - Th.M.)

KIM, H.K. \& VENTER, C.J.H. 1998. Preacher and spirituality: Perspectives from the Pastoral Epistles. In die Skriflig, 32 (2):161-179.

KIM, H.K. \& VENTER, C.J.H. 1999. Equiping the congregation by means of preaching: Paul's sermon at Miletus (Acts 20:17-38) - perspectives for the South African context. In die Skriflig, 33 (4):509-524.

KISTEMAKER, S.J. 1984. Hebrews. Grand Rapids : Baker Book House. (New Testament Commentary.)

LOUW, D.J. 1993. Pastoraat as ontmoeting. Ontwerp vir 'n basisteorie, antropologie, metode en terapie. Pretoria : RGN.

LOUW, D.J. 1987. Bediening en bedienaar. (In Combrink, H.J.B. \& Muller, B.A., red. Huldigingsbundel opgedra aan prof. J.L. de Villiers. Pretoria : Lux Verbi. p. 5571.)

LOUW, J.P. \& NIDA, E.A. 1989. Greek English lexicon of the New Testament (I). New York : United Bible Studies.

MACK, W.A. \& SWAVELY, D. 1996. Life in the Fathers House. A member's guide to the local church. New Jersey : $P$ \& R Publishing.

MAHAN, H.T. 1989. Hebrews. Darlington : Evangelical Press.

MITCHELL, H. 1993. The hearer's experience of the Word. (In O'day, G.R. \& Long, T.G., ed. Listening to the Word. Studies in honor of Fred B. Craddock. Nashville : Abingdon. p. 223-242.)

MÜLLER, J. 1990. Die erediens as fees. Pretoria : NG Kerkboekhandel.

NEL, M. 1994. Gemeentebou. Halfwayhouse : Orion Uitgewers. 
OPPERMAN, W.C. 1995. Die motief van vreemdelingskap en vaderland in Hebreërs - 'n eksegetiese studie met toespitsing op Hebreërs 11:8-22. Potchefstroom : PU vir CHO. (Proefskrif - Th.D.)

OOSTENBRINK, J.W. \& LOTTER, G.A. 1999. Die kleingroepleier as spirituele leier in die gemeente. Praktiese Teologie in Suid-Afrika, 14 (2):43-61.

PFITZNER, V.C. 1993. The rhetoric of Hebrews: Paradigm for preaching. Lutheran Theological Journal, 27 (5):3-12.

PIETERSE, H.J.C. 2001. Prediking in 'n konteks van armoede. Pretoria : Unisa.

RICHARDS, L.O. \& HOELDTKE, C. 1980. A theology of church leadership. Grand Rapids, Mich. : Zondervan.

RUSSELL, B.A. 1996. Fixing your eyes on Jesus. South African Baptist Journal of Theology, 5:140-148.

SMIT, A. 1995. Nuut gedink oor leierskap in gemeentes. (In Burger, C., Hendriks, J., Van der Merwe, M. \& Smit, A., reds. Gemeente en bediening. Nuut gedink oor leierskap in gemeentes. Die begeleiding van 'n Christelike gemeenskap. Kaapstad : Lux Verbi. p.16-36.)

SMITH, R.H. 1984. Hebrews. Minneapolis : Augsburg Publishing House. (Augsburg Commentary on the New Testament.)

VAN DEN BERG, C.M. \& DREYER, T.F.J. 1994. 'n Verkennende studie met die oog op die identifisering en kategorisering van leerteorieë met verwysing na die prediking. Hervormde Teologiese Studies, 50(3):687-712.

VAN DER MERWE, M. 1995. Nuwe treë saam met God. Riglyne en programme oor spiritualiteit en gemeentevernuwing. Kaapstad : Lux Verbi.

VAN DER VYVER, L. du P. \& VENTER, C.J.H. 2000. Die toerusting van gelowiges tot gehoorsaamheid aan die prediking. Praktiese Teologie in Suid-Afrika, 15(2): 169-191.

VAN DER WALT, J.J. 1984. God aan die Woord. Potchefstroom : PU vir CHO. (Departement Diakoniologie.)

VAN WYK, S. 1998. My dominee is hopeloos. Kaapstad : Lux Verbi.

VASQUEZ, M.G. 2000. Correctly forming the public opinion: religious rhetoric, social change and the myth of self-culture. Anglican Theological Review. Special Issue; 14 (3):1-13, Sept.

VENTER, C.J.H. 1986. Gemeente-opbou in die lig van Hebreërs. Potchefstroom : Departement Sentrale Publikasies. (Wetenskaplike bydraes van die PU vir CHO. Reeks H. Inougurele Rede nr. 103.)

VENTER, C.J.H. 1988. Die Gees, die Woord en die bedienaar van die Woord. (In Coetzee, J. C., red. Koninkryk, Gees en Woord. Pretoria : N.G. Kerkboekhandel. p. 141-162.)

VENTER, C.J.H. 1999. Die spiritualiteit van die bedienaar met verwysing na sy toerustingstaak. In die Skriflig, 33(2):187-201, Junie.

VINES, J. 1993. The believers guide to Hebrews. New Jersey : Loizeaux.

VORSTER, J.M. 1995. Vernuwing in die prediking in die lig van hedendaagse lewensbeskoulike tendense. In die Skriflig, 29 (3):443-466, Maart.

WIERSBE, W.W. 1995. Your preaching is unique. Nashville : Moorings.

WILLHITE, K. 1992. Audience relevance in expository preaching. Bibliotheca Sacra, 149(594):355-369. 


\section{Kernbegrippe:}

Hebreërspreek

prediker

prediker as iemand wat verhouding bou

prediker as toeruster

\section{Key concepts:}

Hebrew sermon

preacher

preacher and equipment of the congregation

preacher in multiple relations 
